\title{
Food Safety in Your Home Vegetable Garden
}

PAMELA M. GEISEL, Academic Coordinator, UC Statewide Master Gardener Programs; DONNA C. SEAVER, Program Representative, UC Statewide Master Gardener Program

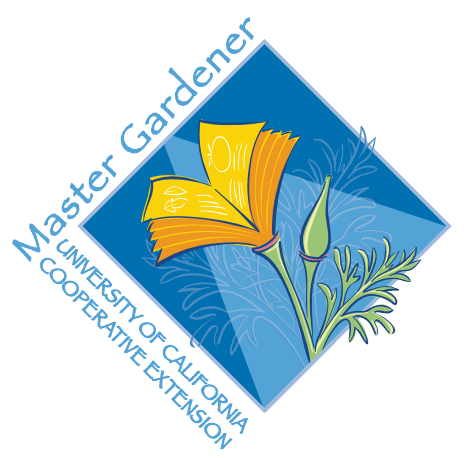

"Outbreaks of foodborne illness make news headlines on a regular basis. In the United States it is estimated that as many as 76 million people contract some type of foodborne illness each year. As a result, over 325,000 are hospitalized and about 5,000 deaths occur." ${ }^{1}$ Everyone is at risk for foodborne illness, but people who are younger than 5 , older than 50 , diabetic, take antibiotics or antacids, and whose immunity is compromised are at a higher risk.

You may have heard about outbreaks of illness from bacteria such as Salmonella on tomatoes and cantaloupe and E. coli O157:H7 on lettuce and spinach. These bacteria that cause foodborne illness can be found in animal droppings and human waste.

From garden to kitchen, there are many chances for bacteria, viruses, and parasites to contaminate produce. Water, tools, animals, and manure-contaminated soil may spread harmful organisms in your garden.

\section{Reduce the Risk of Contaminating the Food Grown in Your Garden}

\section{Clean Soil}

For greatest safety when growing leafy vegetables and other commodities to be eaten raw, consider not using composted/stabilized manure or amendments containing any animal components, even though the risk of foodborne pathogens in properly processed materials is low. If used, incorporate such materials into the soil and do not leave them on the surface.

If manure-based amendments are to be applied to gardens, consider obtaining commercially composted/ stabilized materials. Manure that is composted noncommercially may not be thoroughly processed. However, keep in mind that no compost material is guaranteed to be 100 percent free from bacteria such as E. coli.

\section{Clean Water}

Know about the quality of your irrigation water. Municipal tap water or water from a properly designed well that is tested on a regular basis are preferred sources. Use tap water for overhead irrigation or sprays on the edible parts of plants and when washing produce. 


\section{Clean Hands}

Use protective or disposable gloves when working with manures and compost. Always wash hands thoroughly after working with these materials.

\section{Clean Surfaces}

Before and during harvest use clean tools, gloves, harvest containers, and work surfaces. Be aware of what hands and tools have touched before moving to another task that involves edible plants, especially picking. Hose off tools, shoes, or boots in an area well separated from your vegetable garden. Diluted bleach (1 teaspoon in 4 cups water) or pure white vinegar are safe for sanitizing work surfaces. (For equivalents between U.S. and metric systems of measurement, a conversion table is provided at the end of this publication.)

\section{Consider Food Safety in Each Phase of Your Vegetable Garden}

Follow these guidelines to reduce the risk of exposing the food grown in your garden to contaminants from water, soil and fertilizers, hands, and surfaces.

\section{Pre-Plant}

- Identify water sources for irrigation:

Low risk - municipal drinking water

Minimal risk - potable well water, if well casing is maintained, grouted, and livestock excluded from active recharge area and septic system drain field

Higher risk - surface and reservoir water

- Learn about the quality of your irrigation water and test well or surface water sources for the presence of E.coli and other coliform bacteria (general fecal indicators), which indicate that the water may have been contaminated by fecal sources that can carry harmful pathogens. Below are recommendations for testing water sources. For additional information or local recommendations, consult a county Cooperative Extension educator, California's Department of Health Services (DHS) (http://www.dhs.ca.gov/), or the State Water Board (http://www.swrcb.ca.gov/).

- Municipal water: Backflow prevention devices are recommended.

- Well water: Test twice a year and treat the well if fecal coliform bacteria are present. Contact your county public heath department for guidelines in well treatment and re-test procedures.
- Surface water: A laboratory analysis of surface water will give you the information you need to take corrective measures to provide for suitable and safe water use. Though not common for the home garden, testing during the growing season will help you understand the quality of an available surface water supply and trends that may alert you to contamination-causing activities. Contact your local DHS or Cooperative Extension offices for available laboratory services in your area.

- Home test kits for water quality, including quick tests for fecal indicators, are available for general guidance but have not been evaluated by UC researchers at this time.

- For greatest safety when growing leafy vegetables and other commodities to be eaten raw, consider not using composted/stabilized manure or amendments containing any animal components.

- Avoid using noncomposted manures.

- Avoid planting leafy vegetables and other commodities close to animal enclosures (corrals, feedlots, pastures) where windborne dust and surface water runoff can result in contaminated produce.

\section{Production}

- Be very aware of the potential for garden tools, hands, clothes, and shoes to become contaminated when working with manures and composting materials. Be especially aware that dirty hands or gloves may transfer pathogens from manure or incompletely composted organic materials to crops or containers.

- Use protective or disposable gloves when working with manure and compost, especially if you have open wounds on your hands. Always wash hands thoroughly after working with these materials and, at minimum, hose off tools, shoes, or boots in an area well separated from your vegetable garden.

- Before and after handling fresh fruits and vegetables, wash hands with special attention to cleaning around fingernails.

- Do not add fresh manure to existing compost piles.

- Ideally, keep wild and domestic animals out of compost piles and areas with edible plants during the growing and harvesting season. 
- Minimize risk by using tap water for overhead irrigation or sprays on the edible parts of plants.

- Consider using drip irrigation to reduce wetting of leaf and fruit surfaces.

\section{Harvest}

- Wash hands before handling produce.

- Use clean harvest aids (tools, bins, gloves).

- While in the garden, remove excess soil from produce.

- Handle produce carefully to avoid bruising and damaging.

\section{Postharvest Handling}

- Wash hands before handling produce.

- Use tap water for all washes.

- Remove soil and potential contaminants by washing with a clean brush under running tap water rather than batch-washing in a basin.

- Diluted bleach (1 teaspoon in 4 cups water) or pure white vinegar are safe for sanitizing work surfaces.
- Always cover and refrigerate cut fruit and vegetables when preparing them in advance.

- Throw out cut fruit and vegetables if they have been held for longer than 2 hours at room temperature or longer than 1 hour at temperatures above $90^{\circ} \mathrm{F}\left(32^{\circ} \mathrm{C}\right)$.

Please contact your local Master Gardener for more information or go online to http:// camastergardeners@ucdavis.edu.

We gratefully acknowledge support for this project from the Elvenia J. Slosson Research Endowment for Ornamental Horticulture. Content used in this publication was excerpted with permission from Food Safety Begins on the Farm: Reduce Microbial Contamination with Good Agricultural Practices, by Anu Rangarajan, Marvin Pritts, Steve Reiners, and Laura Pedersen. Our thanks to Trevor Suslow for review and technical input.

Poster design and illustrations: Will Suckow Illustration.

\section{ResourCes ACCESSIBLE ONLINE}

\section{Web Sites}

\section{California Master Gardeners}

http://camastergardeners.ucdavis.edu/

Center for Disease Control

http://www.cdc.gov

Food Safety Fact Sheets and link to EPA Consumer Handbook for composting http://vric.ucdavis.edu

\section{FoodSafe Program}

http://foodsafe.ucdavis.edu

Gateway to Government Food Safety Information http://www.foodsafety.gov/

Good Agricultural Practices Network for Education \& Training http://www.gaps.cornell.edu/

Guide to Minimize Microbial Food Safety Hazards for Fresh Fruits and Vegetables

- Guidance for Industry (FDA)

http://www.foodsafety.gov/ dms/prodguid.html

University of California Good Agricultural Practices

http://ucgaps.ucdavis.edu/

\section{In Spanish}

Las prácticas agrícola buenas de la Universidad de California http://groups.ucanr.org/UC_GAPs/Las_Publicaciones_en_Español/ 


\section{Publications/Brochures}

Good Agricultural Practices - A Self-Audit for Growers and Handlers http://ucce.ucdavis.edu/files/filelibrary/5453/4362.pdf

Harvesting and Storing Your Home Orchard's Nut Crop: Almonds, Walnuts, Pecans

ANR Publication 8005

http://anrcatalog.ucdavis.edu/InOrder/Shop/ItemDetails.asp?ItemNo=8005

Hand Sanitation (ppt to pdf)

http://ucgaps.ucdavis.edu/documents/Slide_presentations2518.pdf

Key Points of Control and Management for Microbial Food Safety: Edible Landscape Plants and Home Garden Produce

\section{ANR Publication 8101}

http://anrcatalog.ucdavis.edu/InOrder/Shop/ItemDetails.asp?ItemNo=8101

Key Points of Control and Management of Microbial Food Safety Concerns for Edible Landscape and Home Gardening (brochure) http://ucce.ucdavis.edu/files/filelibrary/5453/4364.pdf

Microbial Food Safety $\underline{\text { IS }}$ your Responsibility! http://vric.ucdavis.edu/veginfo/foodsafety/foodsafety.htm

\section{National GAPs Educatonal Materials} http://www.gaps.cornell.edu/educationalmaterials.html

Producing Quality Almonds: Food Safety Starts on the Farm ANR Publication 8126 http://anrcatalog.ucdavis.edu/InOrder/Shop/ItemDetails.asp?ItemNo=8126

Safe Handling of Fruits and Vegetables

ANR Publication 8121

http://anrcatalog.ucdavis.edu/InOrder/Shop/ItemDetails.asp?ItemNo=8121

UC Postharvest Technology Research and Information Center

(Food Safety Publications)

http://postharvest.ucdavis.edu/postharvestdata/datareport.cfm?reportnumber=204\&catcol=1809\&cat egorysearch=Food_Safety

\section{In Spanish}

Extensión en español (colección de publicaciones)

http://extensionenespanol.net/publications.cfm

\section{REFERENCES}

1. Rangarajan, A., M. Pritts, S. Reiners, and L. Pedersen. 2000. Food safety begins on the farm: Reduce microbial contamination with good agricultural practices. Ithaca, NY: Cornell University. Good Agricultural Practices (GAP) Program Web site, http://www.gaps.cornell.edu/Educationalmaterials/ Samples/PamphletEng.pdf.

\section{Metric Conversions}

\begin{tabular}{|l|c|c|l|}
\hline English & $\begin{array}{c}\text { Conversion factor for } \\
\text { English to metric }\end{array}$ & $\begin{array}{c}\text { Conversion factor for metric } \\
\text { to English }\end{array}$ & Metric \\
\hline teaspoon (tsp) & 4.93 & 0.20 & milliliter (ml) \\
\hline cup & 236.6 & 0.004 & milliliter (ml) \\
\hline
\end{tabular}




\section{FOR FURTHER INFORMATION}

To order or obtain ANR publications and other products, visit the ANR Communication Services online catalog at http://anrcatalog.ucdavis.edu or phone 1-800-994-8849. You can also place orders by mail or FAX, or request a printed catalog of our products from

University of California

Agriculture and Natural Resources

Communication Services

6701 San Pablo Avenue, 2nd Floor

Oakland, California 94608-1239

Telephone 1-800-994-8849 or 510-642-2431

FAX 510-643-5470

E-mail: danrcs@ucdavis.edu

(C)2009 The Regents of the University of California

Agriculture and Natural Resources

All rights reserved.

No part of this publication may be reproduced, stored in a retrieval system, or transmitted, in any form or by any means, electronic, mechanical, photocopying, recording, or otherwise, without the written permission of the publisher and the authors.

Publication 8366

\section{ISBN-13: 978-1-60107-636-6}

The University of California prohibits discrimination or harassment of any person on the basis of race, color, national origin, religion, sex, gender identity, pregnancy (including childbirth, and medical conditions related to pregnancy or childbirth), physical or mental disability, medical condition (cancer-related or genetic characteristics), ancestry, marital status, age, sexual orientation, citizenship, or service in the uniformed services (as defined by the Uniformed Services Employment and Reemployment Rights Act of 1994: service in the uniformed services includes membership, application for membership, performance of service, application for service, or obligation for service in the uniformed services) in any of its programs or activities.
University policy also prohibits reprisal or retaliation against any person in any of its programs or activities for making a complaint of discrimination or sexual harassment or for using or participating in the investigation or resolution process of any such complaint.

University policy is intended to be consistent with the provisions of applicable State and Federal laws.

Inquiries regarding the University's nondiscrimination policies may be directed to the Affirmative Action/Equal Opportunity Director, University of California, Agriculture and Natural Resources, 1111 Franklin Street, $6^{\text {th }}$ Floor, Oakland, CA 94607, (510) 987-0096. For information about ordering this publication, telephone 1-800-994-8849. For assistance in downloading this publication, telephone 530-754-3927.

To simplify information, trade names of products have been used. No endorsement of named or illustrated products is intended, nor is criticism implied of similar products that are not mentioned or illustrated.

An electronic copy of this publication can be found at the ANR Communication Services catalog Web site, http://anrcatalog.ucdavis.edu.

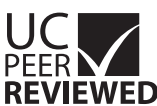

This publication has been anonymously peer reviewed for technical accuracy by University of

REVIEWED California scientists and other qualified professionals. This review process was managed by the ANR Associate Editor for Environmental Horticulture.

pr-08/09-LR/CR 


\section{Ask a UC Master Gardener}
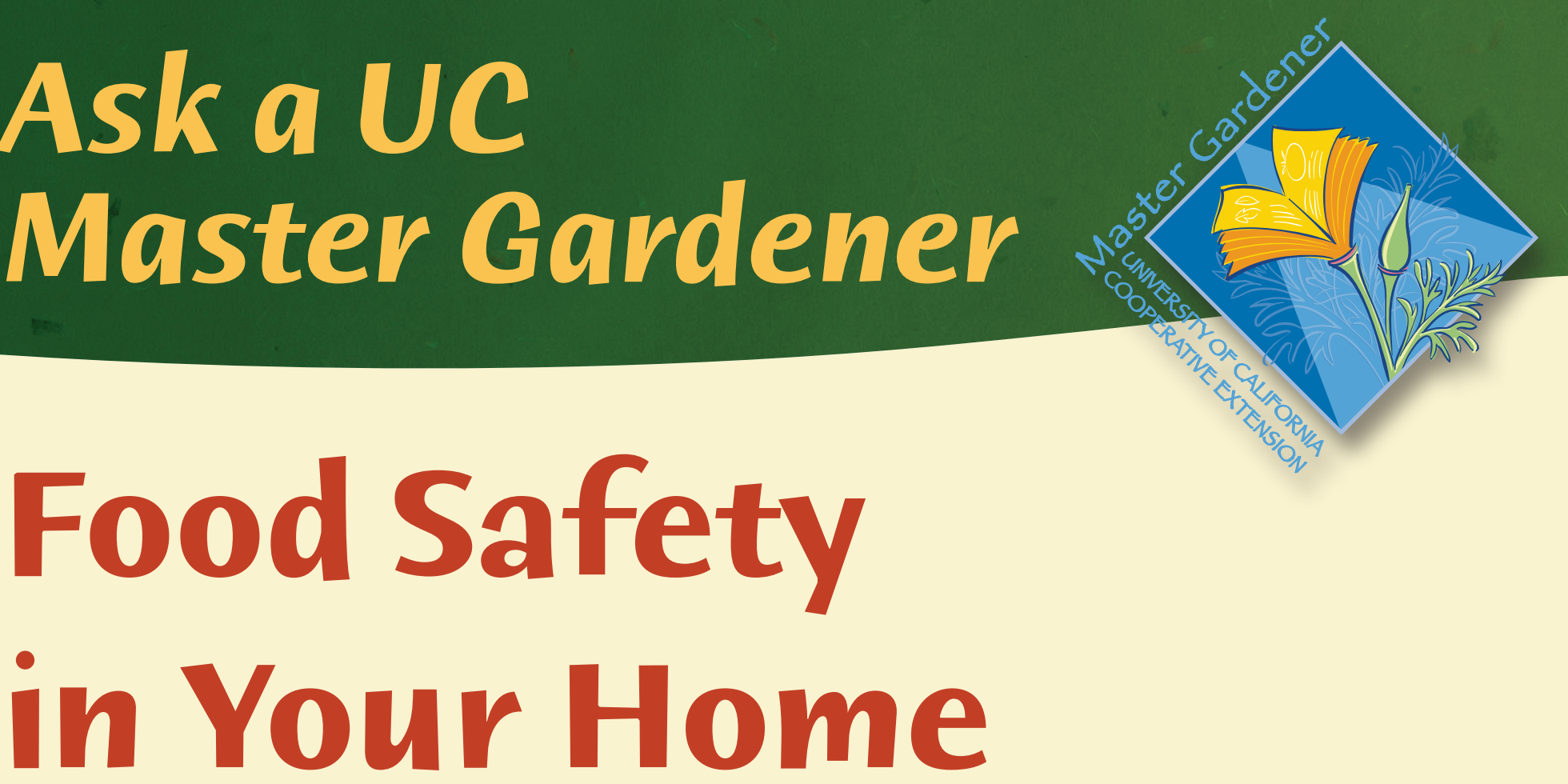

\section{Vegetable Garden}

\section{From garden to kitchen, there are}

many chances for bacteria, viruses, and parasites to contaminate produce.

\section{Water, tools, animals, and manure-} contaminated soil may spread harmful organisms in your garden.

Please contact your local Master Gardener for more information (http://camastergardeners.ucdavis.edu).

We gratefully acknowledge support for this project from the Elvenia J. Slosson Research Endowment for Ornamental Horticulture. Content used in this publication was excerpted with permission from Food Safety Begins on the Farm: Reduce Microbial Contamination with Good Agricultural Practices by Anu Rangarajan, Marvin Pritts, Steve Reiners, and Laura Pedersen. Our thanks to Trevor Suslow for review and technical input.

Project management: Pamela M. Geisel; Donna C. Seaver. Design and illustrations: Will Suckow Illustration.

No endorsement of listed sites, products, or information is intended, nor criticism implied of those not mentioned. The University of California does not discriminate in any of its policies, procedures, or practices. The University is 


\section{Reduce the risk of contaminating}

\section{food grown in your garden}

\section{Clean Soil}

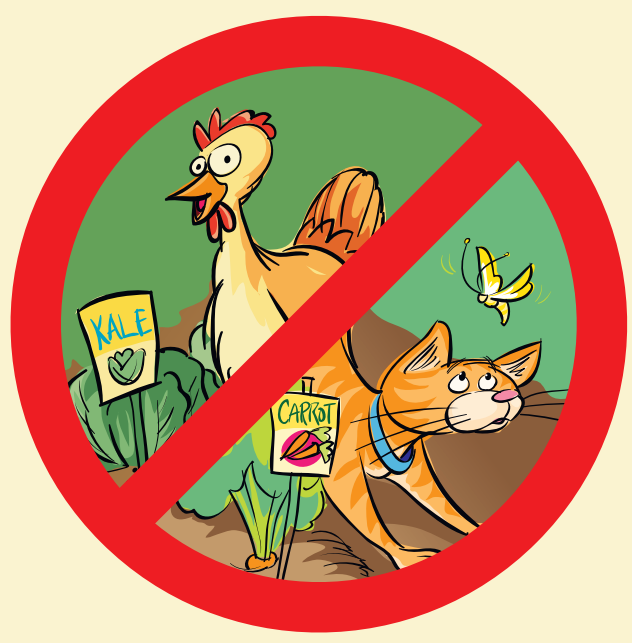

For greatest safety, do not use manure when growing leafy vegetables or other commodities that will be eaten raw.

- Do not add fresh manure to existing compost piles.

- Keep wild and domestic animals out of the garden.

\section{Clean Water}

Know about the quality of your irrigation water.

- Use municipal tap water or water from a properly designed well that is tested regularly for the presence of E.coli bacteria.

- Use drip irrigation to reduce wetting of leaf and fruit surfaces.

- Use tap water for any overhead irrigation or sprays on the edible parts of plants.

- Wash produce under running tap water, rather than batch-washing in a basin.

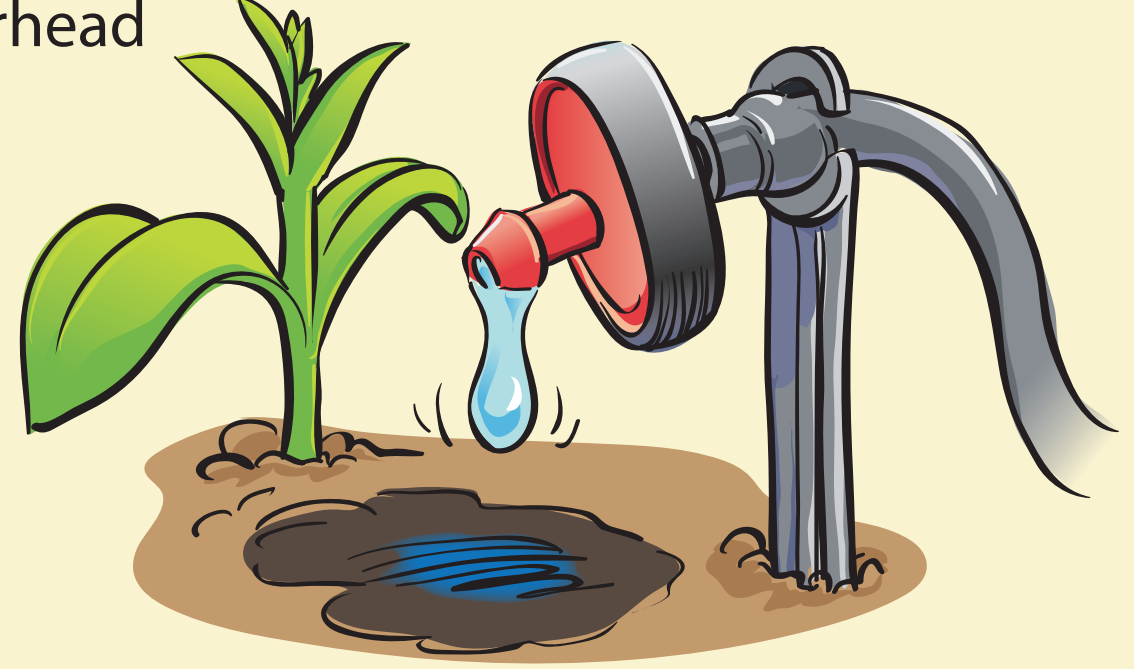




\section{Reduce the risk of contaminating}

\section{food grown in your garden}

\section{Clean Hands}

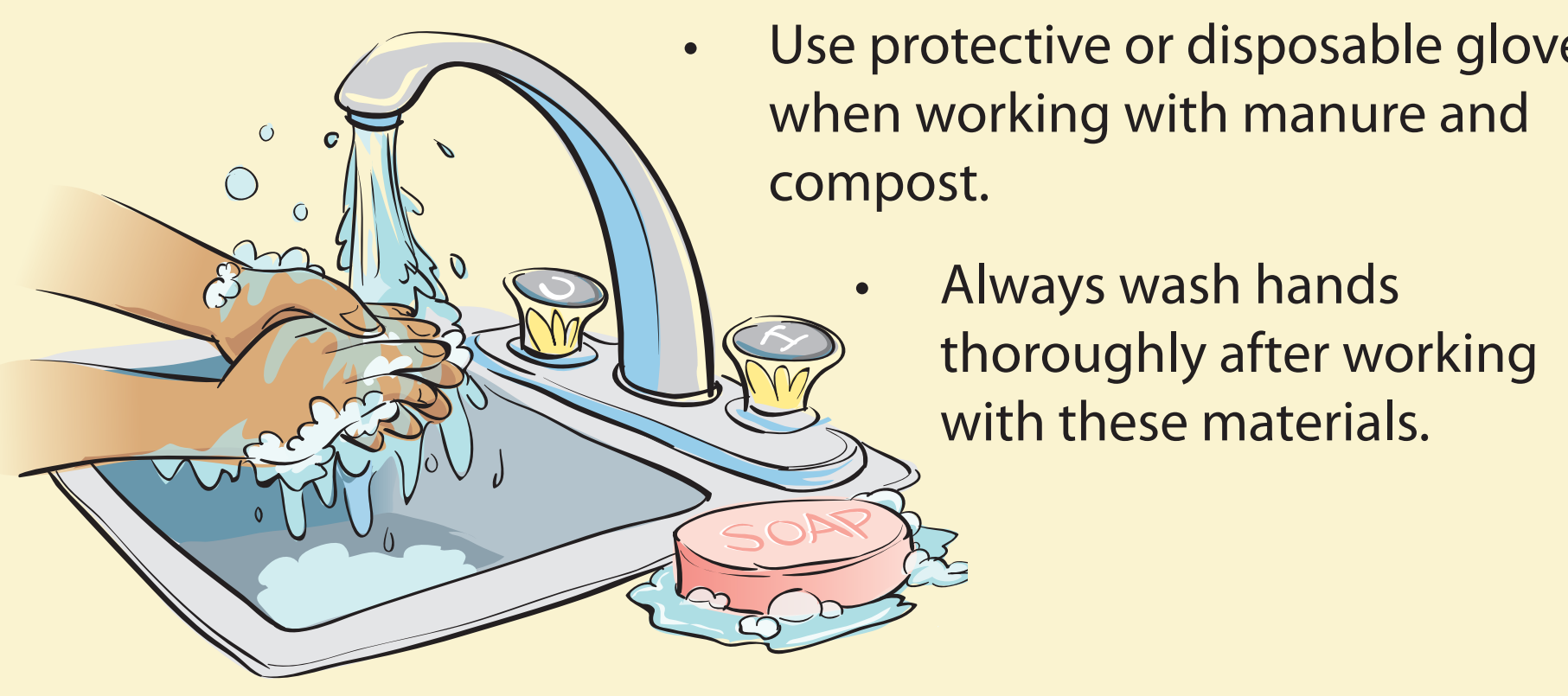

\section{Clean Surfaces}

- Before and during harvest use clean tools, gloves, harvest containers, and work surfaces.

- Hose off tools, shoes, or boots in an area well separated from your vegetable garden.

- Diluted bleach

(1 teaspoon in 4 cups water) or pure white vinegar are safe for sanitizing work surfaces.

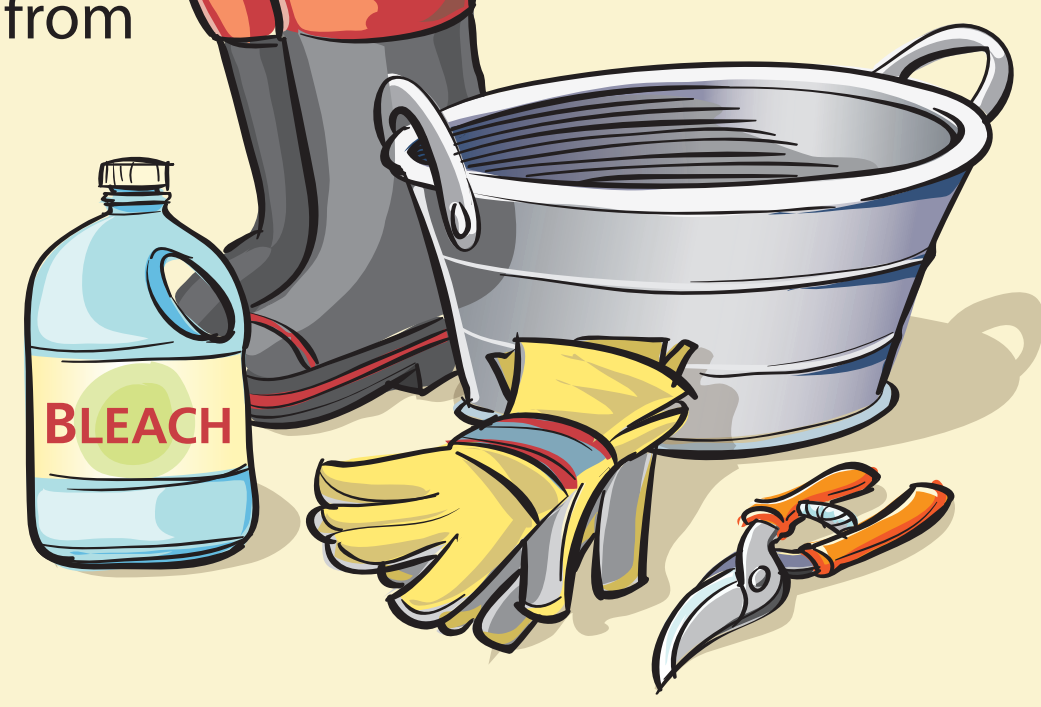

